\title{
Implementation of Smart City Governance Policy in Public Services in The Province of Jakarta, Indonesia
}

\author{
Firman $^{1}$, Sumartono ${ }^{2}$, MR Khairul Muluk ${ }^{3}$ Endah Setyowati ${ }^{4}$ \\ \{fi_rmank@ymail.com ${ }^{1}$, Sumartono_fia@ub.ac.id ${ }^{2}$, mrkhairulmuluk@gmail.com ${ }^{3}$, \\ endah71@gmail.com $\left.{ }^{4}\right\}$ \\ Program Doctor Public Administration Brawijaya University Malang Jl. Veteran, Ketawanggede, \\ Lowokwaru, Kota Malang, Jawa Timur $65145^{1,2,3,4}$
}

\begin{abstract}
This study aims to describe the implementation of smart governance in public services in Jakarta, this was conducted to govern the impact of Jakarta Smart City (JSC) policies where one of the indicators is smart governance related to looking at participation in policymaking, Public services, transparent governance, strategic politics, and perspective. This research was conducted in Jakarta Province specifically on the managers of Jakarta Smart City by conducting in-depth interviews with stakeholders and the community. Interviews were carried out starting from the highest levels of government to the lower levels such as district and task implementers as well as some communities who had used aspiration channels. It was originate that the people of Jakarta participated in assigning the facts, problems in the public complete the aspiration channels provided by Jakarta. This research can be used for universities, teachers, and students. Likewise, in cities in the world, especially cities in Indonesia. In this research, it explains the impact of smart city policies foremost on the pillars of smart governance.
\end{abstract}

Keywords: Smart Governance, Pelayanan Publik, Jakarta Smart City, Digital Governance

\section{Introduction}

Smart city policy in the form of developing technological innovation, governance, and human resource development is the main concern of stakeholders. Such as integration and Stakeholder Engagement (Fernandez-Anez, Fernández-Gïell, \& Giffinger, 2018) and collaboration (Anand \& Navío-Marco, 2018) Some of the previous studies focused a lot on technological innovation and technology development in general, which considered that the key to the smart city was technological readiness, even though the success of the smart city was not merely technological sophistication (Nilssen, 2019).

Smart City (Alawdah, 2017) is related to the need for Smart City Sustainability in theoretical and practicalaspects with the research titled An Exploratory Study of Smart City Initiatives: Theory, Practice, and Sustainability. This research analyzes related to smart cities documented in scientific journals, government websites, and media, as well as what benefits are expected and how the sustainability of smart cities. This research also shows that there are many overlaps between the three dimensions of s mart city (technological innovation, governance, and human capital), which indicate the need for multidisciplinary, interdisciplinary, or transdisciplinary collaborative approaches to integrate theory and maximize the positive potential for smart city sustainability. 
Whereas in the aspect of Smart City with a financial and economic perspective with a collaborative. explained that there are four dimensions of smart city economics, the first is about the scale of the global market for s mart cities, the second problemconcerns the data that will be used forsmart city projects; the third concerns competition and market structure and the fourth concerns the impact on the local economy. This study also focuses on is sues of trans parency and accountability to P.B. citizens (Alawdah, 2017) However, this study focuses more on the pillars of the smart economy.

Public service innovation from the perspective of innovation management and shows that mutualevaluation should not only discuss butalso integrating technological innovation with social innovation. This study is the evaluation of open innovation and public services in the internet-enabled smart cities. An open innovation approach is needed that respects the effectiveness of collaboration with stakeholders as well as how effective it is and the ability to increase social capital both internal and external stakeholders, this can also see their capacity to conduct joint evaluations into the realm of public services that can produce a more complete integrated approach to social-technological innovation this subject is discussed by (Paskaleva \& Cooper, 2018)

However, some things need to be developed so that the public services with the internet can be Tirrenus and successful. An understanding of smart cities is mostly located in small and rural cities. This can be a sign of rejection of the phenomenon in this context. In contrast, middle and large Cities mostly have a comprehensively (Desdemoustier, Crutzen, \& Giffinger, 2019) while (Deakin, Diamantini, \& Borrelli, 2019) focus on providing a synthes is of smart citybased governance to the Internet in the future and continuing to use the understanding of natural resource management wis ely in developing infrastructure innovation in urban areas. the emphasis is on smart city governance which is focused on the pillars of governance that are more participatory and responsive.

In the development of s mart cities, several things have come to the attention of some thinkers, such as the important aspects of digitizing government. as described by (Camero \& Alba, 2019; Paskaleva \& Cooper, 2018; Soyata, Habibzadeh, Ekenna, Nus sbaum, \& Lozano, 2019) The internet and digital systems have changed many things including the way we live and do business. This is also in line with the extraordinary opportunity for Governments to provide better content and services and interact with many communities, businesses and other government partners. it has also provided various facilities in attractive and innovative transactions in carrying out new practices or new ways of governance

Likewise, the social thinkers of humanities, in particular, the fields of business and management that influence the world are (Camero \& Alba, 2019; Paskaleva \& Cooper, 2018; Soyata et al., 2019) predicted that the dark side of Might result from the digital revolution and is proven today, less than 20 years later. Some of the things that Tapscott is interested in include shifting the labor market, loss of privacy, severe economic dis parities, declining quality of life, and the need for governments to adopt digital technology.

Policy interventions in hardware and software infrastructure seem to characterize the concept of Smart Cities but in reality, in the absence of considering local infrastructure, increased exploitation characteristics pose serious risks. The Smart City policy does have a positive impact that cannot be ignored on urban innovation in improving people's welfare. This 
research does not focus on developing innovations primarily on hardware / infrastructure in the development of smart cities. Although it is an important part of developing a smart city, other aspects such as public services

The urgency of this research is to answer the problem of developing a smart city in Jakarta. Based on the range of s mart cities in the world, through the IESE Cities in Motion Index from 2016 to 2018. Data from year to year shows an increase in Jakarta ranking, from previously 170 from 181 countries in 2016 rose to 156 from 180 in 2017. Beigitupun in 2018 is at 138 of 165 countries. This data provides information about Indonesia's position, especially the capital city of Jakarta. The existence of Jakarta's position in the low zone indicates that several aspects must be programmed through policies and programs to be able to match other countries in Southeast Asia. Nevertheless, the policy in managing Jakarta Smart City should be appreciated with various innovations in populist programs so that the dimension of Smart City Governance can continue to increase.

\section{Methodology}

This study was conducted by u sing a qualitative approach that is more focused on case studies in the capitalcity of Jakarta. Data search is carried out in the Jakarta government environment and relevant data in this study. Data obtained from a reliable informant who understand the problems of Jakarta Smart City, from the pers on in charge to the user and the lowest level of government that wards. Thenext step is the extraction of the literature data such as journals, books, research reports, newspapers, websites that are relevant and have a serious relationship in the future affect the study results. in the as pect of data representation, of course consider several things from the selection of informants, the selection of information that unders tands the as pects studied is very important so that the data obtained is in accordance with the reality of the phenomena that arise. The place of research observation is in Jakarta..

\section{Result \& Discussion}

Digitalization of government the practice of digital knowledge in the implementation of government functions or affairs (Muluk, 2008). This is in line with what is contained in the term Electronic Government (e-Govt) as expressed by (Douglas Holmes, 2001) provides a clearer opinion for the public sector that e-government is the use of dataknowledge, especially the net, to provide services better community, close to customers, profitable, and in a diss imilar but improved way.

However, it is not an easy thing to make changes to the government sector. Unlike business sectors that can change quickly to adjust to internal and external dynamics, the public sector usually has a very strong resistance to change. This is indeed also recognized by (Don Tapscott, David Ticoll, 2000) in his very famous book Digital Economy. Similar conditions are als o faced by Indonesia if it wants to digitize the government. Tapscottadded that today's digital network allows all citizens to know what is happening in the city and can contribute their ideas to the way they are governed. To achieve social cohesion, good governance and shared norms, the new reality demands a second wave of democracy based on a culture of public consultation and active citizenship. This is not direct democracy: it's about a new model of civic and political engagement that is appropriate for the 21 st century.

The challenges that will be faced should not beavoided, but ratheridentified and sought out. The identification of the problemis described below. This government digitalization faces a number of challenges related to the conditions of each diverse region. There are many urban 
communities and transitional societies. In addition, there are still many rural communities and there are still people who are still approaching primitive life. With such social police, the digitalization of the government cannot touch all levels of society. Many cities and dis tricts in Indonesia have one type of social type above and many also have several types at once Muluk (2008)

By being aware of this condition, it certainly cannotbe forced that all regions must be able to carry out the digitalization of governance. The first priority is of course given to regions that are ready, especially big cities in Indonesia, such as Jakarta, Surabaya, Malang, Bandung, Medan, Makassar and so on. The next priority will only be given to cities or regencies with typologies of transitional communities.

Tapscott (2000) revealed that Digigov is an internetworked government that replaces the industrial age governor. This change has had the effect of changing from government control to user facility and public authorization from isolated organizational functions to combined reserve services, and from treatment records and working papers to electronic services. In addition, this process brought changes from a time-consuming process to a quick and responsive response, from obvious panels and endorsements to implicit controls and approvals, from physical economic infrastructures to electric fund transfers.

Various developments in the application of information technology in government have experienced several stages up to now. The United Nations identifies five stages in the evolution of e-Government. The phases in question include (Kumar, 2015): Phase 1 (19961999): Appears with a Basic Web Attendance, Phase 2 (1997-2000): Improved with collaborating web, Phase 3 (1998-2003): Collaborative pas s to Contract web, Phase 4 (20002005): Integrative and Transformative web, Phase 5 (2005+): web smart city domination or well-connected web.

The views (Coursey \& Norris, 2008) deliver a respectable review of this matter. The elementary stage is a simple Web attendance where info such as a explanation of the roles offered by the activity, the name of the official responsible, connection details (telephone, email), is providing. This stage was adopted quickly in the mid-90s after the beginning of the Web and speedy adoption of W eb browsers. The another stage is the cooperating stage, where the Web attendance suggestions interface, such as providing a forumfor sending letters (twoway communiqué), or where adminis trative procedures can be moved online, to be occupied from home. A bit of interest near this step is not from a intangible perspective, or from a technical standpoint, but provides significant additional worth in the process.

The big agenda of the DKI Jakarta regional government is in the Jakarta Smart City (JSC) development document that the smart city program should create an effective and efficient city. This is because in big cities like Jakarta sometimes conventional solutions cannot solve increasingly complexurban problems, so we need a 's mart' solution. The problem is whether the solution that is considered smart through the 's mart city' policy can answer the problems of Jakarta residents.

This is also reinforced by the governor's regulation regarding Jakarta Smart City (JSC). Several main objectives can be outlined as follows. (1) improve the quality of information services, policies and public services that are fast (responsive), easy, precise and transparent. (2) synergizing the procedures, systems, facilities, and authority of SKPD / UKPD and/or BUMD in following up on public complaints. (3) guaranteeing the right of the public to submit suggestions, opinions, and reports res ponsibly to the policies and public services of the 
Regional Government using information and communication technology; (4) realizing order and legal certainty in organizing communication and information between the community and the Regional Government based on information and communication technology; (5) integrating all public complaints thatenter the Local Government Official Complaint Channel into the CRM application; and (6) facilitating the coordination of handling public complaints between SKPD / UKPD and/or BUMD.

Conventional methods for handling complaints and public services must be abandoned by the rebels in managing public services. Jakarta Smart City (JSC) development and policy policies must be able and become an instrument for residents in Jakarta's Special Capital Region to get more detailed and quality news in certain services, especially on public complaints. Although it still discusses various is sues that still need to be improved in services, mainly in the aspect of governmentopenness frompublic complaints. known and obtained some information with a number of complaints that enter on government social media such as Twitter, Facebook, and otherQlue applications, which are not clear. However, as a form of transparency, it must be distributed to the public (open data) about the progress of follow-up through aspirations (Qlue Application, Facebook, Twitter) so that the public knows the extent to which community reports have been properly resolved or follow-up

\section{Conclusion}

Digital governance through the expansion of smart city governance that gave birth to the principles of openness and transparency through open data, the existence of a website, with the use of social media tools does not necessarily make good public services.

In this case, it cannot be avoided that the presence and presence of Jakarta Smart City (JSC) has a good and very positive influence, especially if it is only seen from the aspect of accommodating the as pirations of Jakarta citizens in conveying their as pirations. Complaints as well as facts and information around them. This has also influenced the government or service providers in making and providing further policies related to the expansion and quality of public services through smart cities. Various thoughts related to the expansion of Smart Cities are outlined, but this research has not looked at as pects of smart city sustainability in developing countries such as Indonesia.

Expansion and Development of smart city governance that is included in the concept of smart city especially in public services can be tested in the context of developing and expanding responsive and transparent models so as to create and produce effective and efficient smart city management. There are a number of things that need to be considered so that the development and implementation of Smart City can be better, especially in developing countries, at least having to pay attention to technical matters such as several factors, human factors, and institutional factors.

\section{References}

[1] Alawdah, A. (2017). An Exploratory Study of Smart City Initiatives: Theory,Practice, and Linkage to Sustainability.

[2] Anand, P. B., \& Navío-Marco, J. (2018). Governance and economics of smart cities: opport unities and challenges. Telecommunications Policy, 42(10), 795-799. https://doi.org/10.1016/j.telpol.2018.10.001

[3] Camero, A., \& Alba, E. (2019). Smart City and information technology: A review. Cities, 
93(April), 84-94. https://doi.org/10.1016/j.cities.2019.04.014

[4] Coursey, D., \& Norris, D. F. (2008). Models of e-government: Are they correct? An empirical assessment. Public Administration Review, 68(3), 523-536. https://doi.org/10.1111/j.15406210.2008.00888.x

[5] Deakin, M., Diamantini, D., \& Borrelli, N. (2019). The governance of a smart city food system: The 2015 Milan World Expo. City, Culture and Society, 16(January), 5-11. https://doi.org/10.1016/j.ccs.2018.05.004

[6] Desdemoustier, J., Crutzen, N., \& Giffinger, R. (2019). Municipalities' understanding of the Smart City concept: An exploratory analysis in Belgium. Technological Forecasting and Social Change, 142(October), 129-141. https://doi.org/10.1016/j.techfore.2018.10.029

[7] Don Tapscott, David Ticoll, A. L. (2000). Digital Capital: Harnesing The Power Of Businness

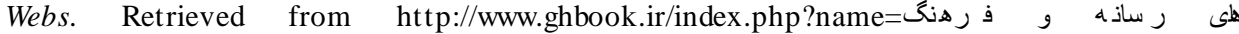
\& ذوي ن \&option=com_dbook\&task=readonline\&book_id=13650\&page=73\&chkhashk=ED9C9491 B4\&Itemid=218\&lang=fa\&tmpl=component

[8] Douglas Holmes. (2001). eGov eBusiness Strategies for Government. In Nicolas Brealey Publishing, London.

[9] Fernandez-Anez, V., Fernández-Güell, J. M., \& Giffinger, R. (2018). Smart City implementation and discourses: An integrated conceptual model. The case of Vienna. Cities, 78(June), 4-16. https://doi.org/10.1016/j.cities.2017.12.004

[10] Kumar, T. M. V. (2015). E-Governance for Smart Cities. In Springer. https://doi.org/10.1007/978981-287-287-6_1

[11] Muluk, Kh. M. . (2008). KNOWLEDGE MANAGEMENT (Kunci Sukses Inovasi Pemerintahan Daerah). 1-300.

[12] Nilssen, M. (2019). To the smart city and beyond? Developing a typology of smart urban innovation. Technological Forecasting and Social Change, 142(December 2017), 98-104. https://doi.org/10.1016/j.techfore.2018.07.060

[13] Paskaleva, K., \& Cooper, I. (2018). Open innovation and the evaluation of internet -enabled public services in smart cities. Technovation, 78(August 2014), 4-14. https://doi.org/10.1016/j.technovation.2018.07.003

[14] Soyata, T., Habibzadeh, H., Ekenna, C., Nussbaum, B., \& Lozano, J. (2019). Smart city in crisis: Technology and policy concerns. Sustainable Cities and Society, 50(October 2018), 101566. https://doi.org/10.1016/j.scs.2019.101566 